\title{
Peroxidases in Tobacco Abscission Zone Tissue. VI. Ultrastructural localization in plasmodesmata during ethylene-induced abscission
}

\author{
Egbert W. Henry \\ Department of Biological Sciences, Oakland University, \\ Rochester, Michigan 48063, U.S.A.
}

Received May 31, 1977

It has been suggested that peroxidases can mediate the oxidation or decarboxylation of indol-3yl-acetic acid (IAA) in vitro (Beaudreau and Yasanobu 1966, Galston, Bonner and Baker 1953, McCune 1961, Morita, Kameda and Mizano 1962), thus controlling growth caused by the reduction of IAA in the tissue (van Overbeek 1935). The incidence of peroxidase activity in plant tissues appears to be ubiquitous; therefore, it is possible that this enzyme may be involved in cell wall extensibility (Ridge and Osborne 1970), ethylene biosynthesis (Mapson and Wardale 1972) and disease resistance (Kosuge 1969, Seevers, Daly and Catedral 1971).

With respect to bean leaf abscission, several reports have thoroughly described the gross anatomy (Brown and Addicott 1950, Scott, Miller, Webster and Leopold 1967, Osborne 1968, Webster 1968, 1970, Webster and Leopold 1972, Webster and Chiu 1975).

In tobacco flower pedicel abscission zone tissue, there have been several studies on both naturally occurring (Jensen and Valdovinos 1967, 1968, Valdovinos and Jensen 1968) and ethylene-induced (Valdovinos, Jensen and Sicko 1971, Henry, Valdovinos and Jensen 1971, Jensen and Valdovinos 1972, Valdovinos, Jensen and Sicko 1972, Henry and Jensen 1973, Henry, Valdovinos and Jensen 1974, Henry 1974, 1975a, 1975b, 1977) abscission.

The use of diaminobenzidine (DAB) in fine-structural cytochemistry was initially introduced by Graham and Karnovsky (1966), when they reported on the fine structural localization of horesradish peroxidase activity. Diaminobenzidine (DAB) has since been used to ultrastructurally identify peroxidase activity in leaf peroxisomes (Israel and Steward 1967), chloroplast thylakoids (Nir and Seligman 1970, Henry, Valdovinos and Jensen 1971, Henry and Jensen 1973, Henry 1975a, 1975b), kidney peroxisomes (Beard and Novikoff 1969, Fahimi 1969) and to characterize cytochrome c oxidase activity in mitochondria (Seligman, Karnovsky, Wasserkrug and Hanker 1968).

There are other reports on the use of DAB to indicate enzymatic activity in plant tissues (Frederick and Newcomb 1969, Vigil, 1969, 1970, Henry, Valdovinos and Jensen 1971, Henry and Jensen 1973, Henry 1975a, 1975b).

The inclusion of potassium cyanide, a generalized inhibitor of heme-containing enzymes, such as peroxidase, in the DAB incubation medium, results in a reduced degree of staining (Vigil 1969, 1970, Hepler, Rice and Terranova 1972). It has been 
reported that aminotriazole, a specific inhibitor of catalase activity, does not obviate peroxidase staining of DAB-incubated tissue in biochemical assays (Margoliash and Novogrodsky 1958, Margoliash, Novogrodsky and Schejter 1960), in animals (Fahimi 1968, 1969, 1970) and in plants (Frederick and Newcomb 1969, Vigil 1969, 1970, Hepler, Rice and Terranova 1972).

Ethylene-treated tobacco flower pedicel abscission zone tissue, in biochemical assays, shows a significant increase in endogenous peroxidase between $3 \mathrm{hr}$ and $5 \mathrm{hr}$ in exposure (Henry, Valsovinos and Jensen 1971, Henry, Valdovinos and Jensen 1974). Also, it has recently been reported that both peroxidase and RNase activities of older (7 week) tobacco callus tissue were substantially higher than in younger ( 4 week) tissue, suggesting that rising levels of these enzymes may be concerned with plant tissue senescence (Vetter 1973).

Earlier studies revealed that ethylene-treated tobacco flower pedicels show a 30-fold increase in the proliferation of rough endoplasmic reticula (RER) between $2 \mathrm{hr}$ and $5 \mathrm{hr}$ of ethylene exposure (Valdovinos, Jensen and Sicko 1971). Also, ultrastructural studies indicated the localization of peroxidase in the rough endoplasmic reticula of ethylene-treated pedicels (Henry 1975b).

Accordingly, an investigation was undertaken to ascertain if ethylene treatment had any effect on plasmodesmata in tobacco abscission zone flower pedicel tissue.

\section{Materials and methods}

The tobacco plants were grown in the greenhouse with subsequent exposure or non-exposure to ethylene as previously described (Henry and Jensen 1973).

Tissue segments containing the abscission zone were excised from the pedicels of the flowers at the beginning of the experiment and then at hourly intervals beginn ing $1 \mathrm{hr}$ after the initiation of ethylene $(5 \mu \mathrm{l} / \mathrm{l})$ exposure. The tissue was fixed immediately in $3 \%$ glutaraldehyde $(50 \%$ aqueous solution, Fisher in $0.1 \mathrm{M}$ phosphate buffer, $\mathrm{pH} \mathrm{7.2)} \mathrm{for} 1 \mathrm{hr}$ at $4^{\circ}$. Other tissue segments were collected and fixed for $2 \mathrm{hrs}$ at room temperature in a mixture of $2 \%$ glutaraldehyde buffered with $0.05 \mathrm{M}$ collidine plus $0.06 \mathrm{M}$ sucrose at $\mathrm{pH} 7.3-7.4$. The tissue sections were then rinsed for $1 \mathrm{hr}$ in collidine buffer.

Each individual $2 \mathrm{~mm}$ section of flower pedicel tissue was cut into four smaller sections before transfer to the diaminobenzidine (DAB) incubation medium of Novikoff and Goldfisher (1969).

The incubation medium contained $10 \mathrm{mg}$ of 3,3'-diaminobenzidine tetrachloride (DAB, Sigma), $0.1 \mathrm{ml}$ of $3 \%$ hydrogen peroxide and $5 \mathrm{ml}$ of 2-amino-2methyl-1, 3-propandiol buffer (0.05 M, pH 9.0).

Sections of flower pedicel tissue, fixed and sliced as described above, were incubated for $1 \mathrm{hr}$ at $37^{\circ}$ in one of the following: a) complete diaminobenzidine (DAB) staining medium; b) complete medium minus diaminobenzidine (DAB); and c) complete diaminobenzidine (DAB) medium minus hydrogen peroxide. The tissue sections were then rinsed several times in $0.05 \mathrm{M}$ propandiol buffer, $\mathrm{pH} 9.0$. For inhibition studies, the tissue sections were pre-incubated for $1 \mathrm{hr}$ at $37^{\circ}$ in either $0.02 \mathrm{M}$ 3-amino-1, 2, 4-triazole (Aldrich) or $0.02 \mathrm{M}$ potassium cyanide. The tissue 
segments were incubated in complete diaminobenzidine (DAB) medium for $1 \mathrm{hr}$ at $37^{\circ}$ containing either $0.02 \mathrm{M}$ 3-amino-1, 2, 4-triazole or $0.02 \mathrm{M}$ potassium cyanide. The respective tissue sections were then rinsed several times in $0.05 \mathrm{M}$ propandiol buffer, $\mathrm{pH}$ 9.0. The diaminobenzidine (DAB) incubation procedure was carried out for all tissue segments at separate ionic strengths of $\mathrm{pH} 9.0$ and $\mathrm{pH} 6.0$ (Novikoff and Goldfischer 1969).

Tissue sections were post-fixed with $2 \%$ osmium tetraoxide in $0.01 \mathrm{M}$ phosphate buffer, $\mathrm{pH} 7.2$ for $1 \mathrm{hr}$. Dehydration was carried out in a graded ethanol series, followed by treatment with propylene oxide, with embedding in Epon 812 (Luft 1961).

Tissue samples selected for sectioning were taken at various depths in the cortical tissue of the abscission zone area. Sections were cut on an LKB ultramicrotome using a diamond knife, and collected on 300 mesh copper grids. Sections were examined without counter stain or with post-staining in lead or uranyl salts, separately, or in combination. The prepared sections were examined with either a Hitachi HU 11E or Philips 300 electron microscope using $75 \mathrm{kV}$.

\section{Results}

Three hour ethylene-treated tissue incubated with DAB medium containing the catalase inhibitor aminotriazole, shows peroxidase staining in the plasmodesmata (PL), rough endoplasmic reticula (RER) and middle lamellar (ML) areas of the cell walls (CW). The microbody (MB) does not show staining as it contains catalase (Fig. 1).

Five hour ethylene-treated tissue, incubated in medium without DAB, shows extensive vesiculation (arrows) near edges of the cell walls $(\mathrm{CW})$. Also, the plasmodesmata (PL) appear to be closely apposed to the middle lamellar $(\mathrm{ML})$ dissolution areas of the cell walls $(\mathrm{CW})$. The plasmodesmata $(\mathrm{PL})$ appear to be continuous with the plasma membranes (PM) of the adjacent cells (Fig. 2).

Five hour ethylene-treated tissue, incubated in DAB medium, show peroxidase localization sites throughout the cell walls (CW). Also, portions of the remaining plasmodesmata (PL) show peroxidase staining (arrows). Peroxidase stained rough endoplasmic reticula (RER) and extensive cell wall (CW) vesiculation (CV) is present (Fig. 3).

Five hour ethylene-treated tissue, incubated in DAB medium, shows peroxidase staining throughout the middle lamellar $(\mathrm{ML})$ areas of the cell walls $(\mathrm{CW})$ and plasmodesmata (PL). The plasmodesmata (PL) appear to transverse the cell wall (CW) and become continuous with the respective adjacent plasma membranes (PM) (Fig. 4).

Three hour ethylene-treated tissue incubated in DAB medium, shows peroxidase staining in the cell walls $(\mathrm{CW})$. The plasmodemsata (PL) are not continuous across the cell walls $(\mathrm{CW})$ and are slightly more peroxidase dense than the corresponding cell wall (CW) staining (Fig. 5).

Non-ethylene-treated tissue, incubated in DAB medium, shows peroxidase localization sites within the single membrane-bound granular component $(\mathrm{GC})$ of 


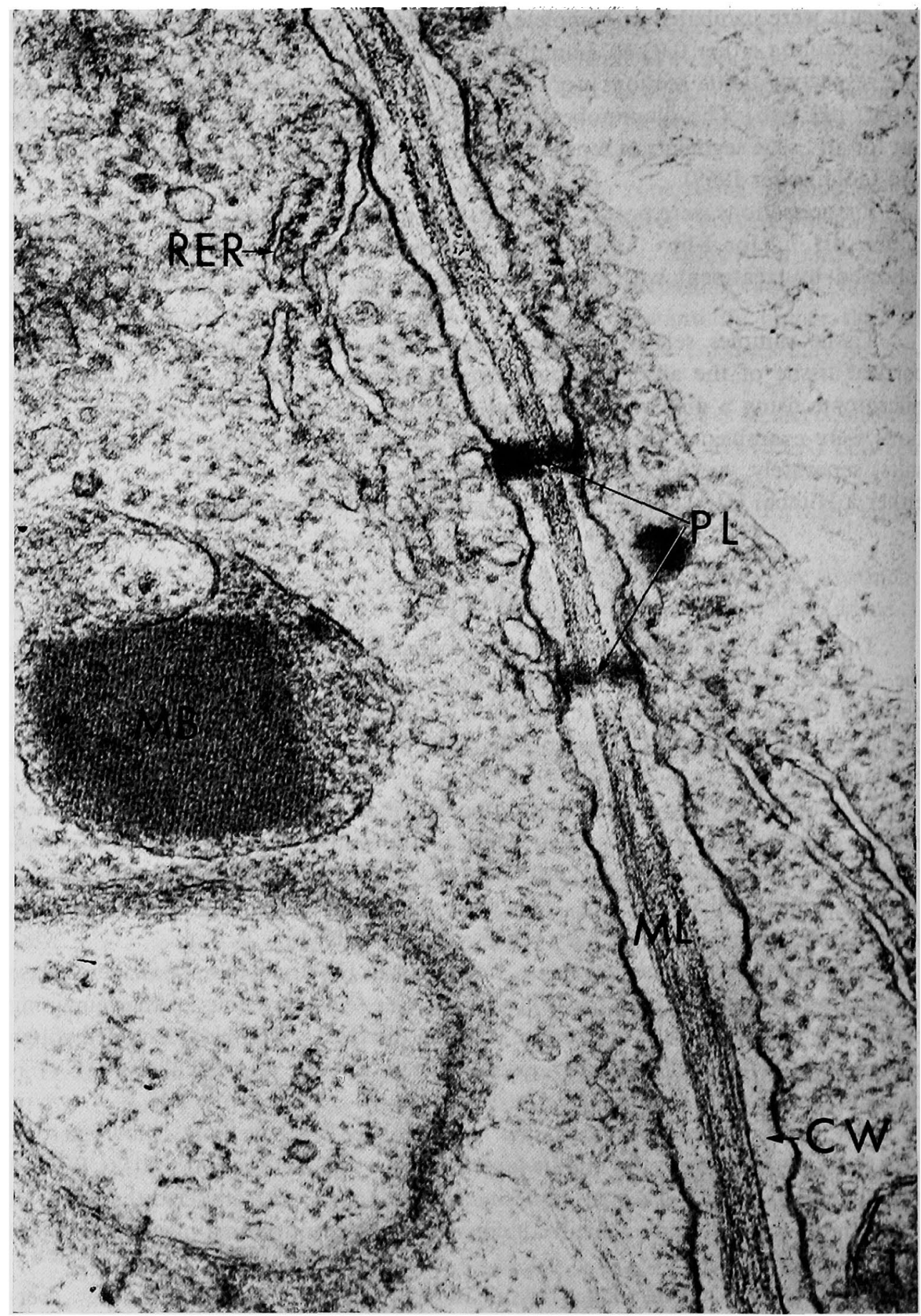

Fig. 1. Portion of abscission zone cortical tissue treated with $5 \mu \mathrm{l} / \mathrm{l}$ ethylene for $3 \mathrm{hr}$ and incubated in $\mathrm{DAB}$ medium containing aminotriazole. Peroxidase staining is present in the plasmodesmata (PL) rough endoplasmic reticulum (RER) and middle lamellar (ML) areas of the cell walls (CW). The microbody (MB) does not show DAB reaction product as it contains catalase. Glutaraldehyde$\mathrm{OsO}_{4}$ fixation with uranyl acetate poststaining. $\times 66,000$. 


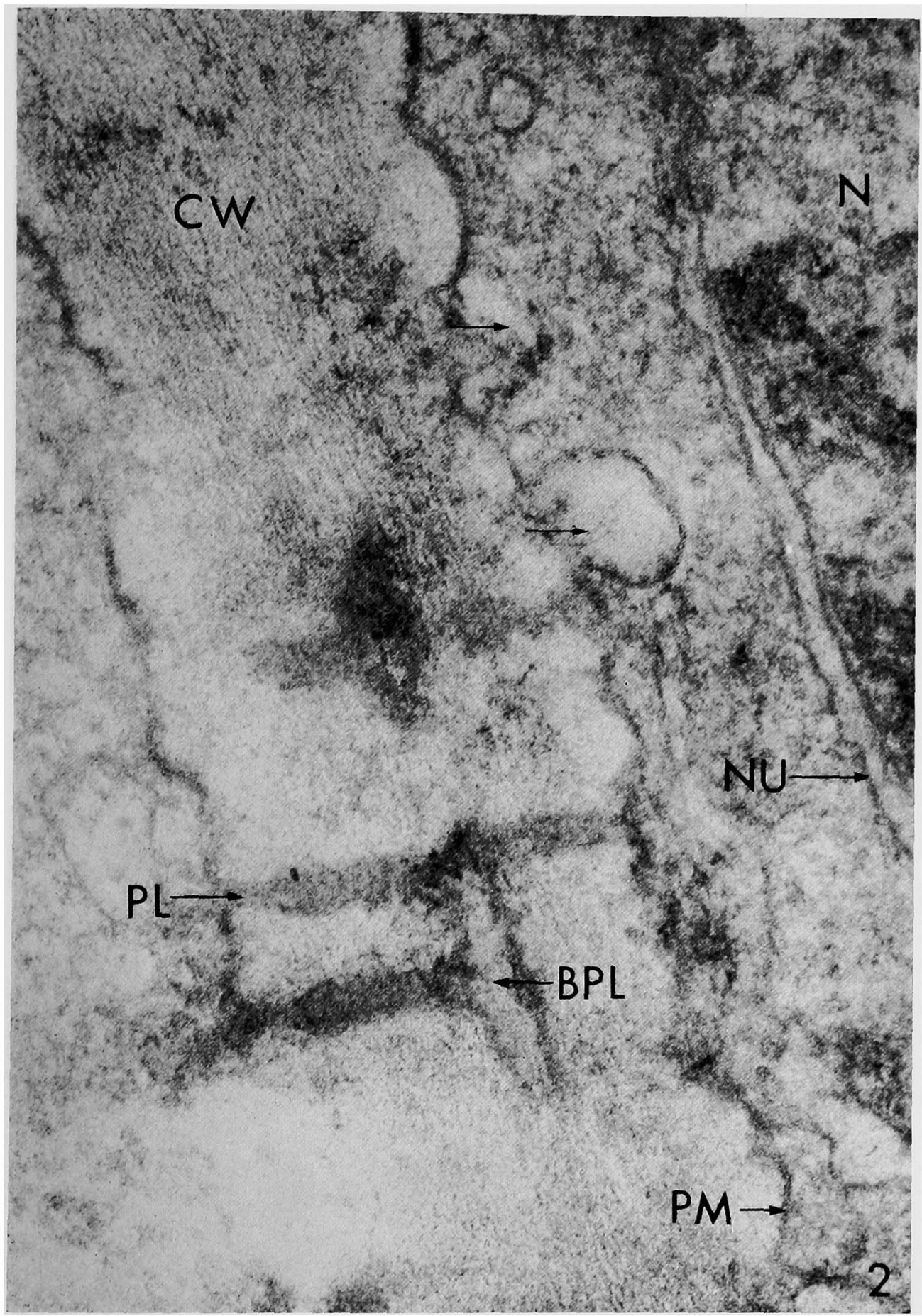

Fig. 2. Portion of abscission zone cortical tissue treated with $5 \mu \mathrm{l} / \mathrm{l}$ ethylene for $5 \mathrm{hr}$ and incubated in DAB medium. Extensive vesiculation (arrows) is present near the edges of the cell walls (CW). The bulging plasmodesmata (BPL) appear to be closely apposed to the middle lamellar (ML) dissolution areas of the cell walls (CW). The plasmodesmata (PL) appear to be continuous with the plasma membranes (PM) of the adjacent cells. A portion of the nuleus $(\mathrm{N})$ and its nuclear membrane (NU) are also present. Glutaraldehyde- $\mathrm{OsO}_{4}$ fixation without poststaining. $\times 63,000$. 


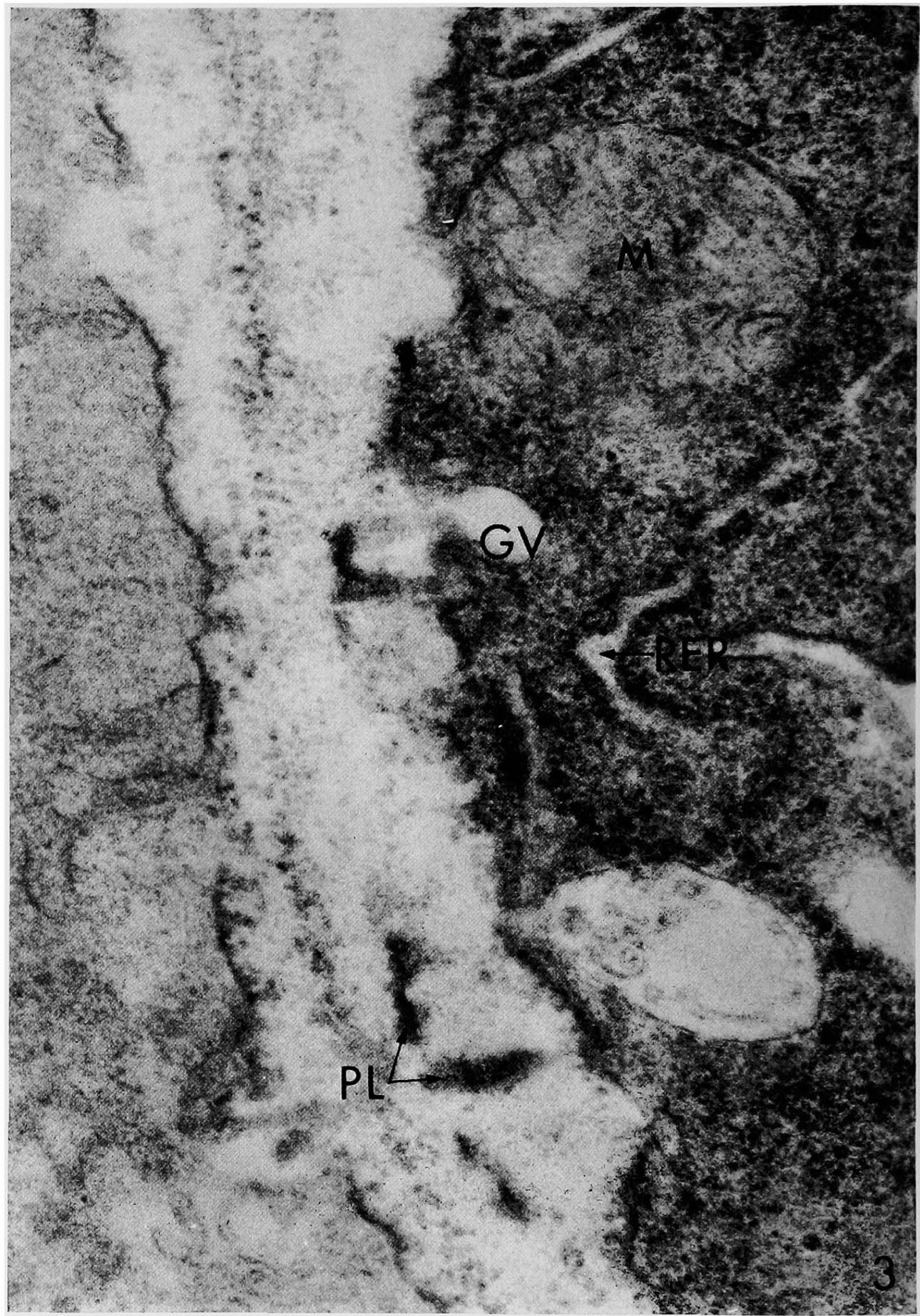

Fig. 3. Portion of abscission zone cortical tissue treated with $5 \mu \mathrm{l} / \mathrm{l}$ ethylene for $5 \mathrm{hr}$ prior to incubation in DAB medium. DAB reaction product is present throughout the cell walls $(\mathrm{CW})$. Remnants of the remaining plasmodesmata (PL) show peroxidase staining (arrows). Peroxidase stained rough endoplasmic reticula (RER) extensive cell wall $(\mathrm{CW})$ vesiculation $(\mathrm{CV})$ and mitochondria (M) are present. Glutaraldehyde- $\mathrm{OsO}_{4}$ fixation with no poststaining. $\times 59,000$. 


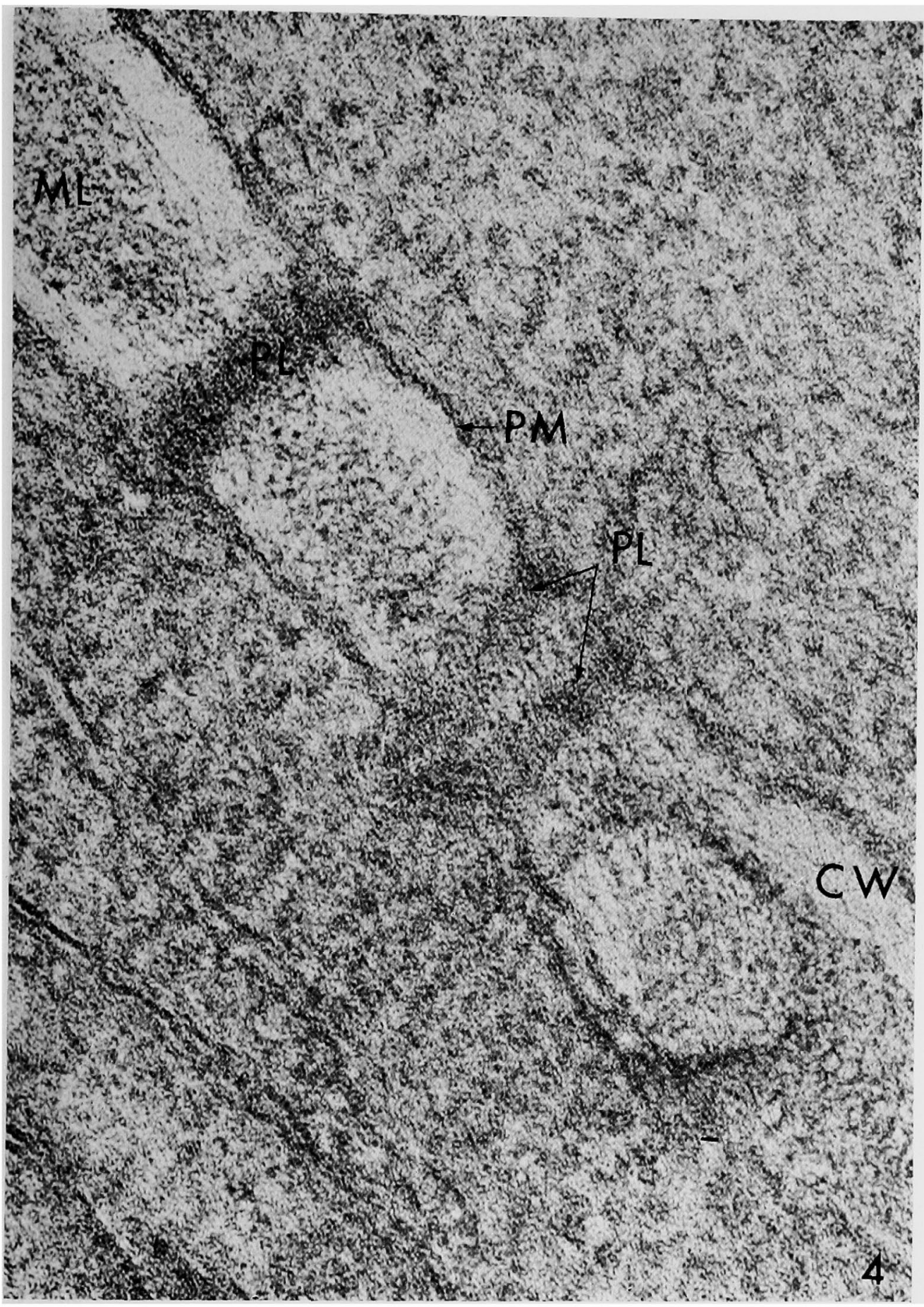

Fig. 4. Portion of abscission zone cortical tissue treated with $5 \mu \mathrm{l} / \mathrm{l}$ ethylene for $5 \mathrm{hr}$ prior to incubation in DAB medium. DAB reaction product is present in the middle lamellar (ML) of the cell walls $(\mathrm{CW})$ and plasmodesmata $(\mathrm{PL})$. The plasmodesmata $(\mathrm{PL})$ appear to traverse the cell wall $(\mathrm{CW})$ and become continuous with the adjacent plasma membranes (PM). Glutaraldehyde$\mathrm{OsO}_{4}$ fixation with uranyl acetate and lead citrate poststaining. $\times 61,000$. 


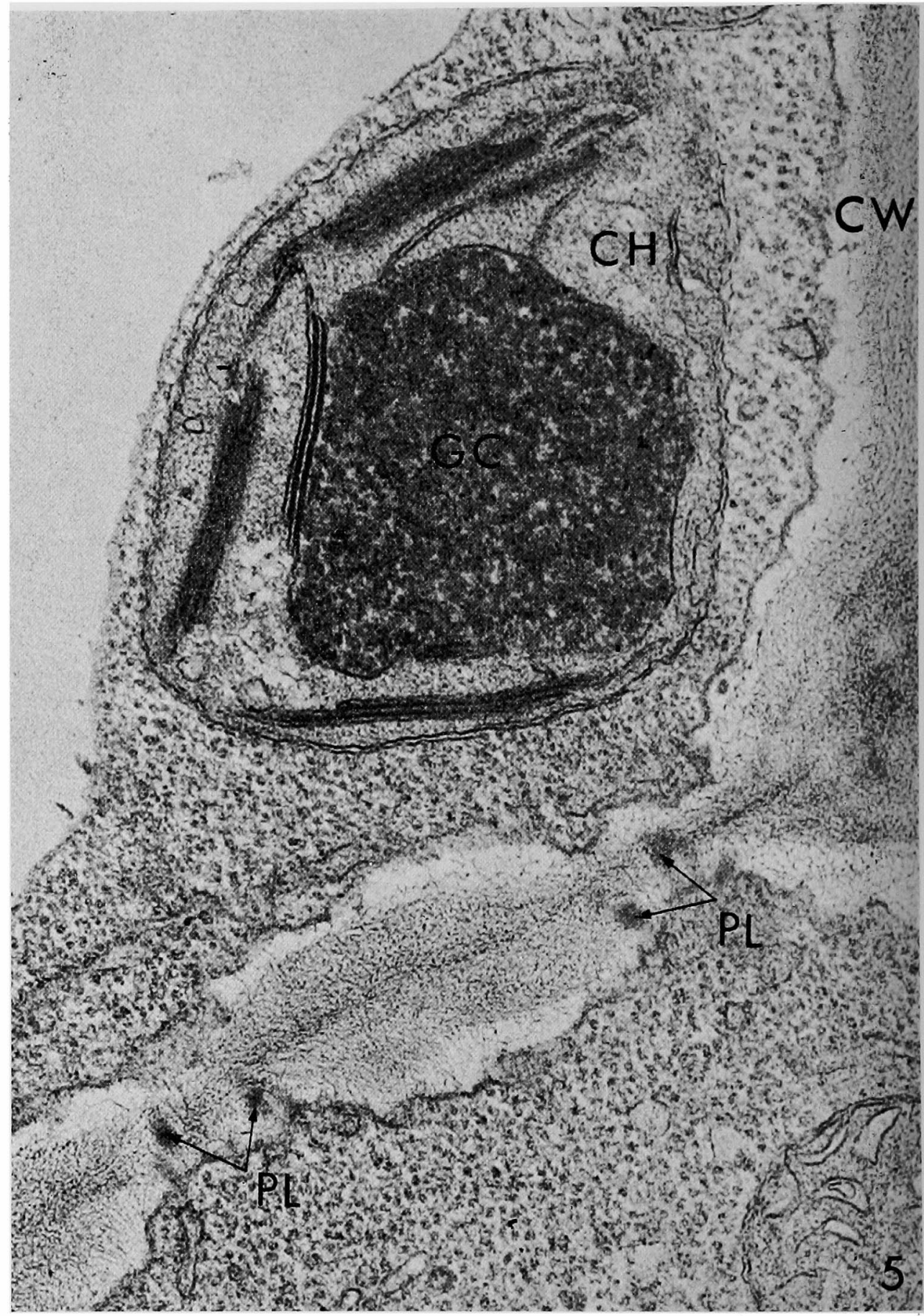

Fig. 5. Portion of abscission zone cortical tissue, treated with $5 \mu \mathrm{l} / 1$ ethylene prior to incubation in $\mathrm{DAB}$ medium, shows peroxidase staining in the cell walls $(\mathrm{CW})$ and remnants of plasmodesmata (PL). The plasmodesmata (PL) are not continuous across the cell walls (CW) and are slightly more dense than the corresponding cell wall $(\mathrm{CW})$ staining reactions. A chloroplast $(\mathrm{CH})$ with a single membrane-bound granular component (GC) is also present. Glutaraldehyde-OsO $\mathrm{O}_{4}$ fixation with uranyl acetate poststaining. $\quad \times 30,000$. 


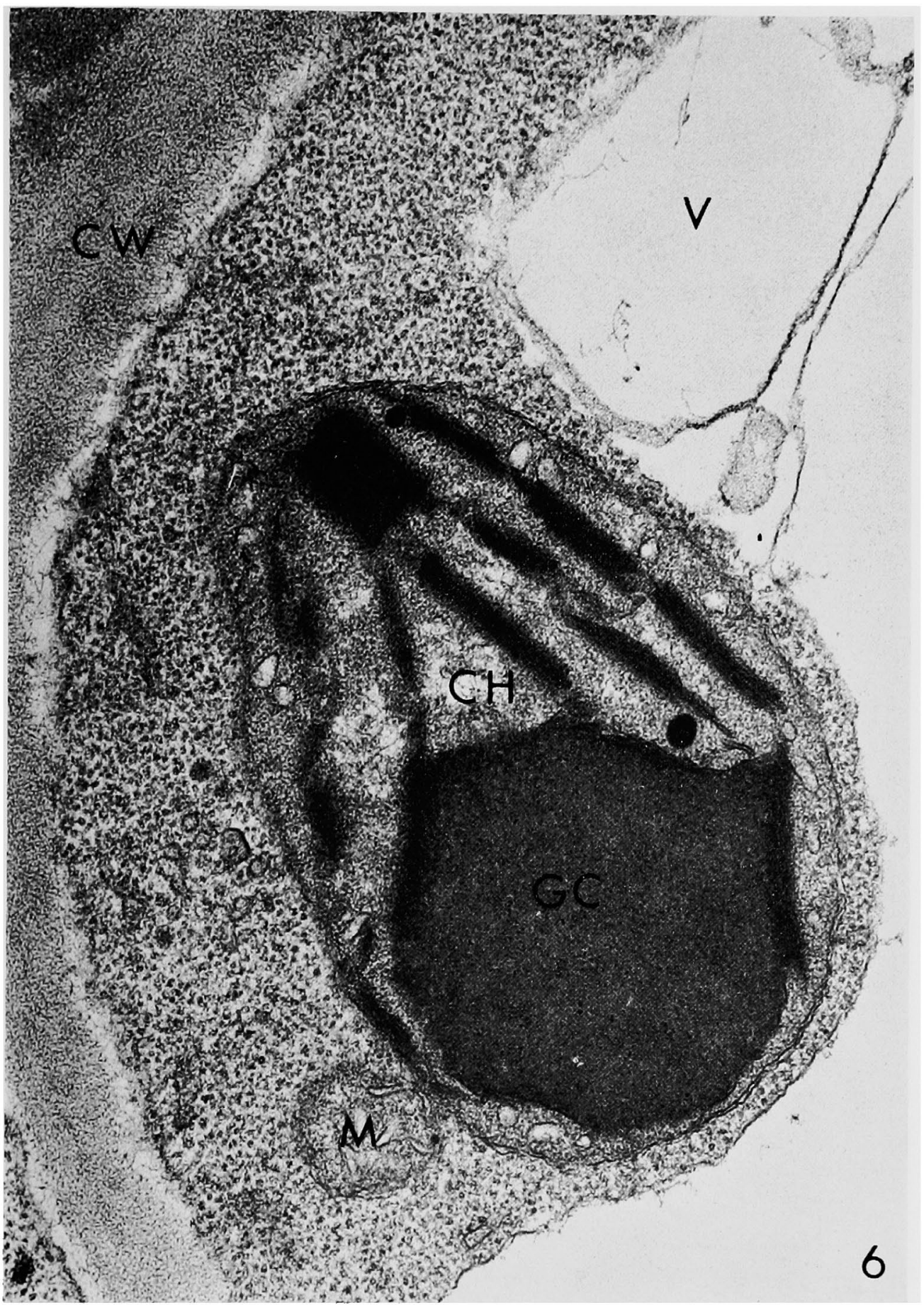

Fig. 6. Portion of abscission zone cortical tissue, non-ethylene-treated and incubated in DAB medium. DAB reaction product is present within the single membrane-bound granular component (GC) of the chloroplast $(\mathrm{CH})$. The cell walls $(\mathrm{CW})$ show peroxidase staining. A mitochondrion (M) and vacuole are visible. Plasmodesmata are not present. Glutaraldehyde- $\mathrm{OsO}_{4}$ fixation with uranyl acetate and lead citrate poststaining. $\times 30,000$. 


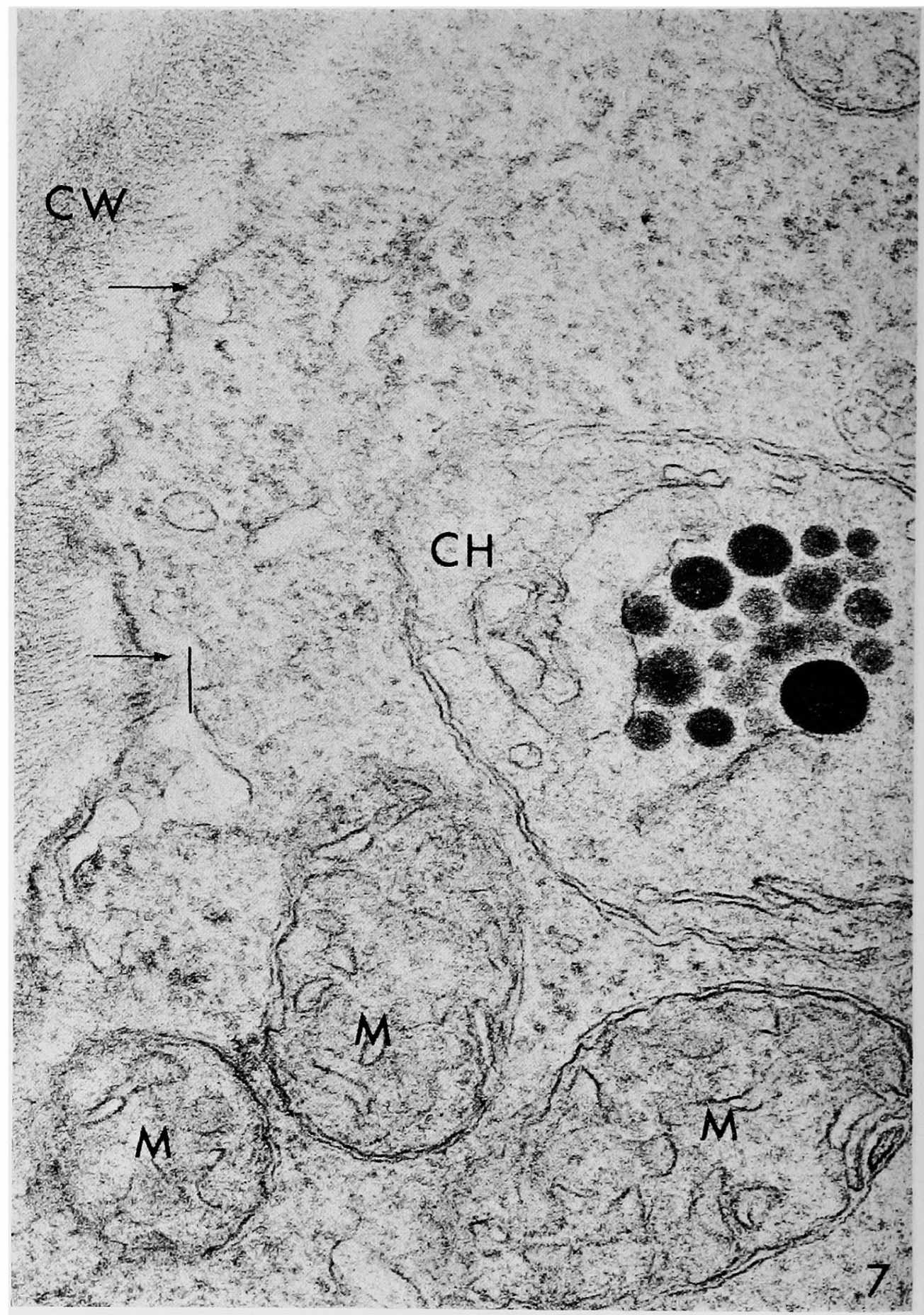

Fig. 7. Portion of abscission zone cortical tissue, non-ethylene-treated, with DAB incubation. The cell walls $(\mathrm{CW})$ have extensive sites of vesiculation (arrows). Mitochondria (M) and a chloroplast $(\mathrm{CH})$ are also present. Glutaraldehyde- $\mathrm{OsO}_{4}$ fixation with uranyl acetate and lead citrate poststaining. $\times 67,000$. 


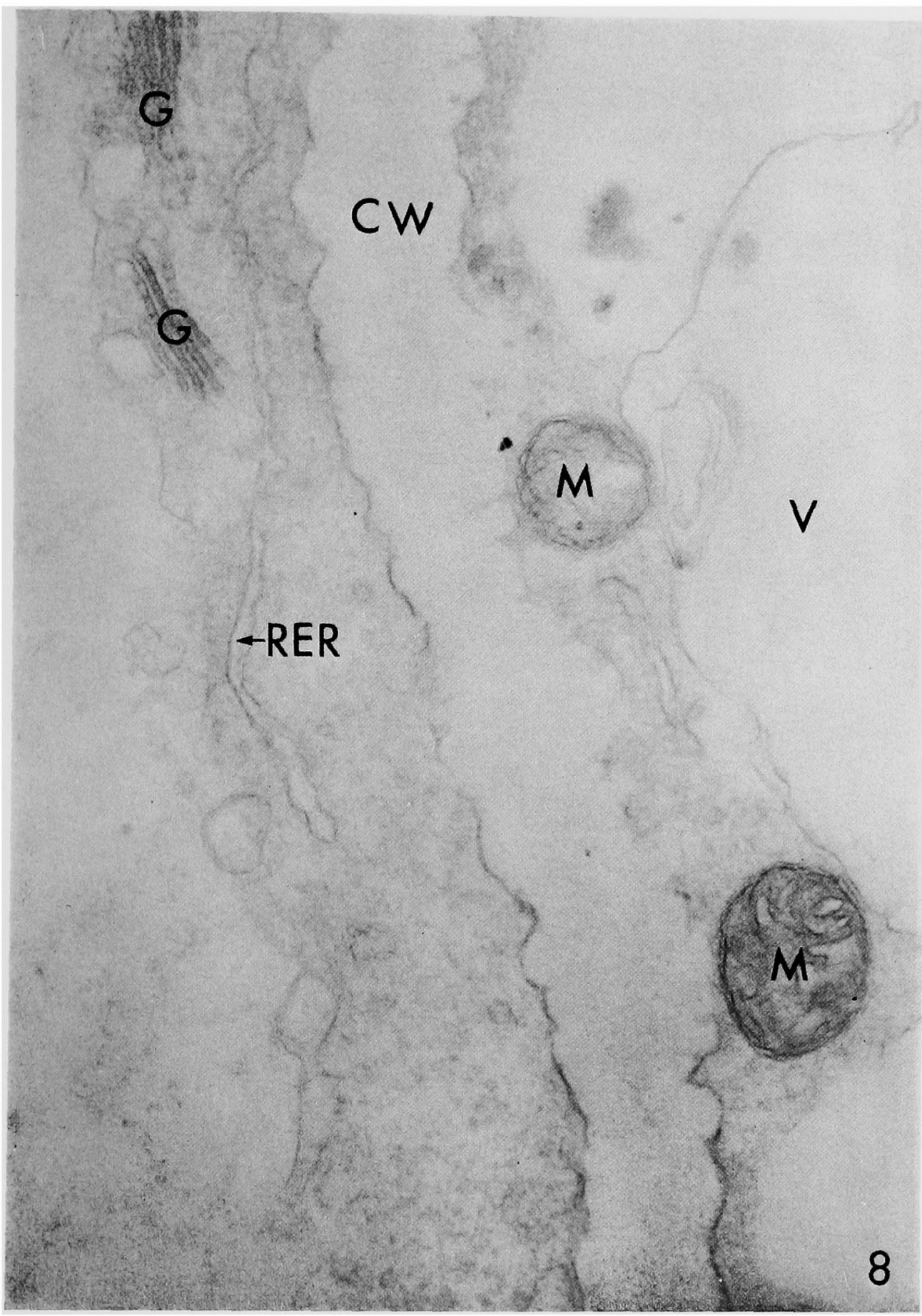

Fig. 8. Portion of abscission zone cortical tissue, treated with $5 \mu \mathrm{l} / \mathrm{l}$ ethylene for $5 \mathrm{hr}$ prior to incubation in DAB medium containing potassium cyanide. There is an absence of DAB reaction product in the cell walls (CW). Remnants of degraded plasmodesmata (PL) connections are present (arrows) along the edges of the cell walls. A vacuole (V) mitochondria (M), rough endoplasmic reticula (RER) and Golgi (G) are also present. $\mathrm{OsO}_{4}$ fixation without poststaining. $\times 24,000$. 


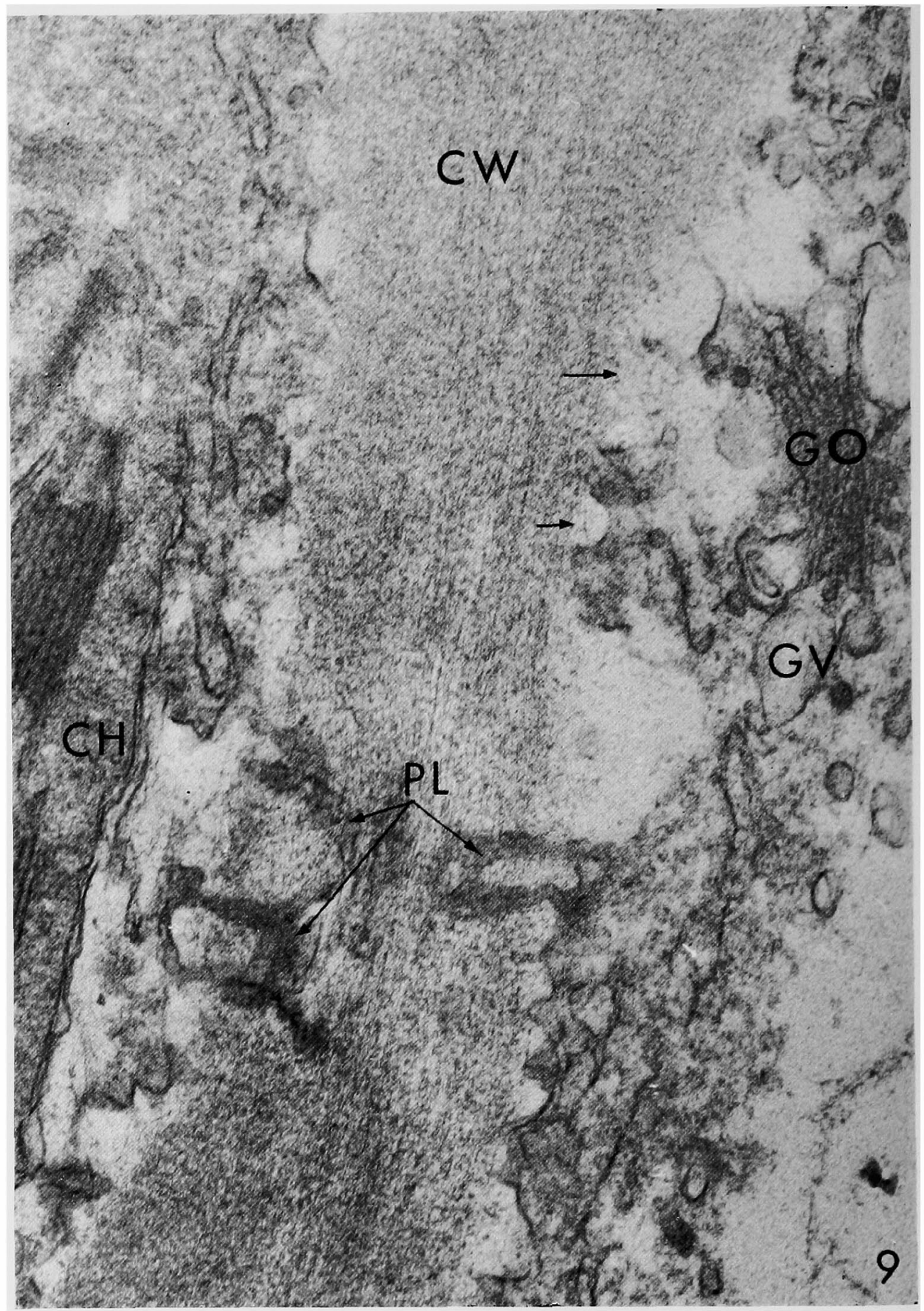

Fig. 9. Portion of abscission zone tissue, treated for $5 \mathrm{hr}$ with $5 \mu \mathrm{l} / \mathrm{l}$ ethylene, prior to incubation in DAB medium. DAB reaction product is present in the cell walls (CW), Golgi vesicles (GV), cisternae (GO) and plasmodesmata (PL), which are undergoing dissolution. Extensive cell wall $(\mathrm{CW})$ vesiculation (arrows) is visible. A portion of a chloroplast $(\mathrm{CH})$ is also present. Glutaraldehyde- $\mathrm{OsO}_{4}$ fixation without poststaining. $\times 37,000$. 


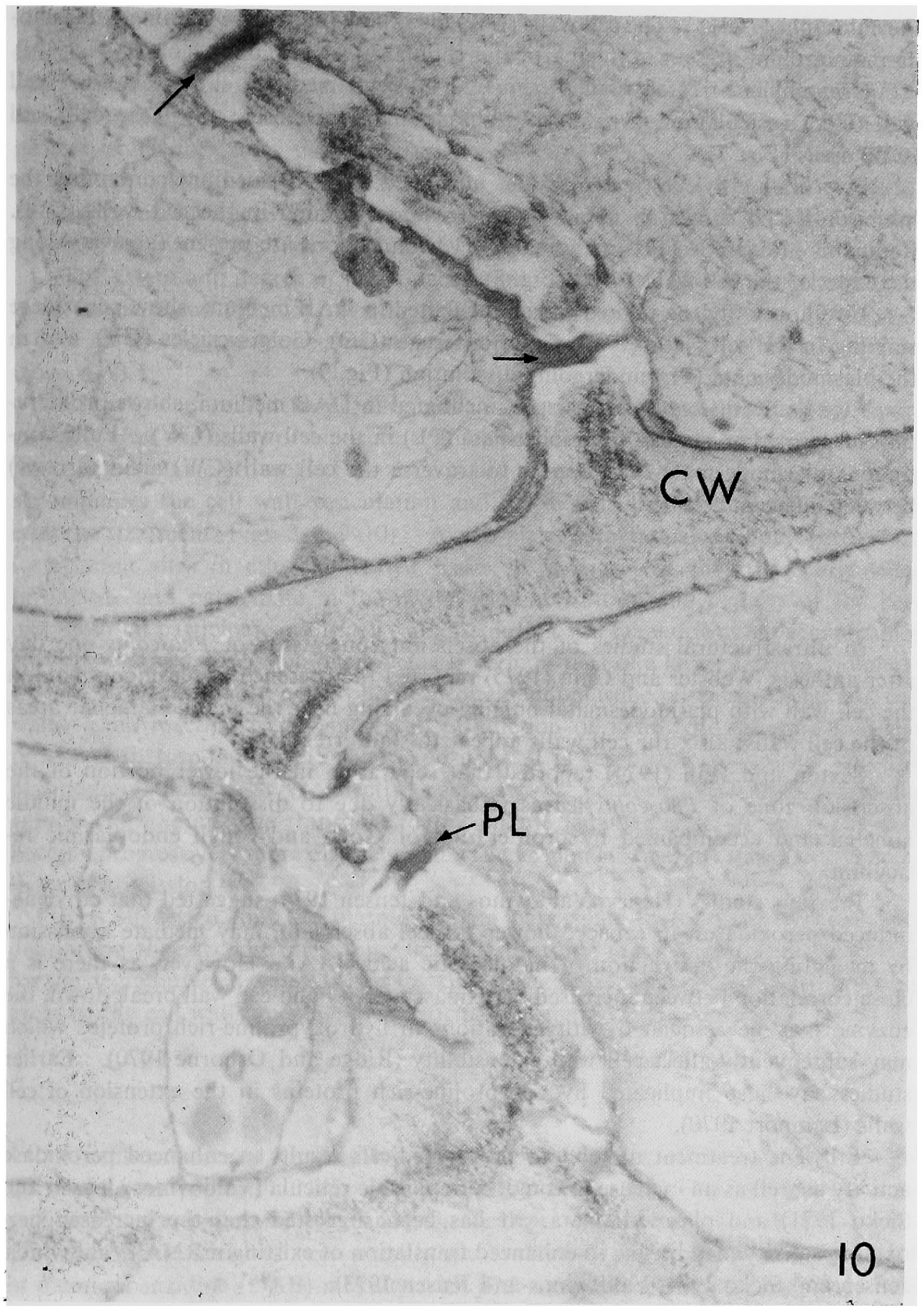

Fig. 10. Portion of abscission zone cortical tissue, treated for $5 \mathrm{hr}$ with $5 \mu \mathrm{l} / \mathrm{l}$ ethylene, prior to incubation in DAB medium. There is a proliferation of peroxidase-stained plasmodesmata (PL) in the cell walls $(\mathrm{CW})$. Some plasmodesmata $(\mathrm{PL})$ traverse the cell walls $(\mathrm{CW})$ areas (arrows) between the adjacent cells. Glutaraldehyde- $\mathrm{OsO}_{4}$ fixation without poststaining. $\times 33,000$. 
the chloroplast $(\mathrm{CH})$. The cell walls $(\mathrm{CW})$ also show peroxidase staining. Plasmodesmata are not present in this particular cellular area (Fig. 6).

Non-ethylene-treated tissue, incubated in DAB medium, shows extensive cell wall $(\mathrm{CW})$ vesiculation (arrows). Plasmodesmata are absent from the cell wall (CW) areas (Fig. 7).

Five hour ethylene-treated tissue, incubated in DAB medium containing the inhibitor $\mathrm{KCN}$, shows an absence of peroxidase staining in the cell walls (CW). Remnants of degraded plasmodesmatal (PL) connections are present (arrows) along the edges of the cell walls (CW) (Fig. 8).

Five hour ethylene-treated tissue, incubated in DAB medium, show peroxidase staining in the cell walls (CW), Golgi cisternae (GO), Golgi vesicles (GV), and in the plasmodesmata (PL) undergoing dissolution (Fig. 9).

Five hour ethylene-treated tissue, incubated in DAB medium, shows proliferation of peroxidase stained plasmodesmata $(\mathrm{PL})$ in the cell walls $(\mathrm{CW})$. Fully continuous plasmodesmata (PL) appear to traverse the cell wall (CW) areas (arrows) between adjacent cells (Fig. 10).

\section{Discussion}

In ultrastructural studies of the abscission zone tissue of Phaseolus one day after anthesis, Webster and Chiu (1975) reported the presence of plasmodesmata in the cell wall with plasmodesmatal bulging occurring near the middle lamellar areas of the cell walls; also, the cell walls appear to stain irregularly.

Sexton and Hall (1974) reported that separation in the lower portion of the abscission zone of Phaseolus leaves is basically due to dissolution of the middle lamellar and accompanied by proliferation of Golgi and rough endoplasmic reticulum.

Previous studies (Henry, Valdovinos and Jensen 1974) suggested that ethyleneinduced peroxidases, in tobacco flower pedicel abscission, may mediate abscission by mediating the destruction of indoleacetic acid (IAA). However, as there is a close correlation between increased peroxidase activity and cell wall break down, the enzyme may be associated with alterations in hydroxyproline-rich proteins which may subsequently affect cell wall extensibility (Ridge and Osborne 1970). Earlier studies have also implicated hydroxyproline-rich proteins in the extension of cell walls (Lamport 1970).

Ethylene treatment of tobacco flower pedicels results in enhanced peroxidase activity as well as an increase in rough endoplasmic reticula (Valdovinos, Jensen and Sicko 1971) and plasmodesmata. It has been suggested that the increased peroxidase activity may be due to enhanced translation of existing mRNA (Valdovinos, Jensen and Sicko 1971, Valdovinos and Jensen 1973).

In a study of bean explants, it was reported that protein mobilization occurs from the distal region of the abscission zone to the proximal region (Scott and Leopold 1966). In tobacco flower pedicel abscission, ethylene treatment results in high protein levels in the proximal abscission zone tissue (after 4 hrs of ethylene exposure) at the same time that the abscission zone tissue itself demonstrates the 
highest amount of peroxidase activity (Henry, Valdovinos and Jensen 1974). These studies suggested that peroxidase was present in an inactive form outside of the abscission layer, prior to ethylene treatment (Henry, Valdovinos and Jensen 1974).

The ethylene inducement of increased peroxidase activity in tobacco flower pedicel abscission zone tissue occurs concomitantly with cell wall dissolution, particularly in the middle lamellar (Henry and Jensen 1973). In addition, the increased peroxidase activity, in response to ethylene, is evident in the rough endoplasmic reticula, Golgi vesicles, Golgi cesternae and plasmodesmata.

The extent and degree of peroxidase staining is slightly less in three hour ethylene-treated tissue (Fig. 5) than in five hour ethylene-exposed tissue (Figs. 2-4, 9-10). Non-ethylene-treated tissue shows a lack of peroxidase staining reaction (Figs. 6-7).

All ethylene-treated tissue demonstrates extensive cell wall breakdown, particularly after five hours of exposure, with peroxidase localization being concentrated in the middle lamellar areas (Figs. 2-5, 9-10). The proliferation of plasmodesmata accompanies the cell wall vesiculation and dissolution that occurs in response to ethylene treatment (Figs. 2-5, 9-10). As the plasmodesmata also exhibit peroxidase localization sites in ethylene-treated tissue, it is suggested that these organelles proliferate and participate in the increased mobilization and activity of the peroxidases that participate in the cell wall dissolution and breakdown that accompanies ethylene-induced abscission phenomena is perhaps part of a larger enzyme mobilization process that involves microbodies, rough endoplasmic reticulae, Golgi and cell walls - each reacting to the increased production of hydrolytic enzymes that are produced in response to ethylene exposure. It is reasonable to suggest that the plasmodesmata serve as "connective passageways" between adjacent cells and are vehicles for the enzyme transport to the middle lamellar areas of cell walls that become progressively more distinct during the terminal $(3 \mathrm{hr}-5 \mathrm{hr})$ stages of ethyleneinduced abscission.

It is suggested that the plasmodesmata participate in the enhanced cell wall dissolution that accompanies abscission via affording more mobilization pathways for the degradative enzymes, in this instance peroxidase, to reach the middle lamellar areas of the cell walls and thereby participate in the resultant dissolution processes.

\section{Summary}

The ultrastructural localization of peroxidases, during ethylene-induced abscission, in flower pedicels of Nicotiana tabacum L. cv. 'Little Turkish', has been investigated. Peroxidase activity has been localized in the plasmodesmata of abscission zone tissue that had been fixed in glutaraldehyde and subsequently incubated in diaminobenzidine (DAB) medium with post-fixation in osmium tetroxide. Preincubation of tissue in potassium cyanide, prior to incubation in DAB medium containing the inhibitor, demonstrates a significant reduction in DAB staining. Incubation of tissue in aminotriazole (an inhibitor of catalase activity), prior to incubation in DAB medium containing the inhibitor, does not inhibit the peroxidase activity in plasmodesmata incubated in DAB medium; however, aminothiazole does 
inhibit catalase present in the microbodies of DAB incubated tissue. It is suggested that proliferating plasmodesmata, in response to ethylene treatment, exhibit enhanced peroxidase activity and allow for the increased mobilization of peroxidase to the middle lamellar areas of the cell walls of abscising cells.

\section{Acknowledgements}

The author wishes to express appreciation for the use of the electron microscope and laboratory facilities so kindly provided by Professors Thomas E. Jensen and Jack G. Valdovinos, Department of Biological Sciences, Herbert H. Lehman College of the City University of New York, Bronx, NY 10468.

The author wishes to express appreciation for the use of the electron microscope and laboratory facilities so kindly provided by Professor Nalin J. Unakar, Chairman, Department of Biological Sciences, Oakland University, Rochester, Michigen 48063.

\section{References}

Beard, M. E. and Novikoff, A. B. 1969. Distribution of peroxisomes (microbodies) in the nephron of the rat. A cytochemical study. J. Cell Biol. 42: 501.

Beaudreau, C. and Yasinobu, K. T. 1966. Heme proteins VI. Crystalline pineapple peroxidase. B. Biochemistry 5 : 1405-1412.

Brown, H. S. and Addicott, F. T. 1950. The anatomy of experimental leaflet abscission in Phaseolus vulgaris. Amer. J. Bot. 37: 650-656.

Fahimi, H. D. 1968. Cytochemical localization of peroxidase activity in rat hepatic microbodies (peroxisomes). J. Histochem. Cytochem. 16:547.

- 1969. Cytochemical localization of peroxidatic activity of catalase in rat hepatic microbodies (peroxisomes). J. Cell Biol. 43: 275.

- 1970. The fine structural localization of endogenous and exogenous peroxidase activity in kupffer cells of rat liver. J. Cell Biol. 47: 247-262.

Frederick, S. E. and Newcomb, E. H. 1969. Cytochemical localization of catalase in leaf microbodies (peroxisomes). J. Cell Biol. 43: 343-353.

Galston, A. W., Bonner, J. E. and Baker, R. S. 1953. Flavoprotein and peroxidases as components of the indoleacetic acid oxidase of peas. Arch. Biochem. Biophys. 42: 456-470.

Graham, R. C. and Karnovsky, M. J. 1966. The early stages of injected horseradish peroxidase in the proximal tubules of mouse kidney; ultrastructural cytochemistry by a new technique. J. Histochem. Cytochem. 14: 291-302.

Hall, J. L. and Sexton, R. 1972. Cytochemical localization of peroxidase activity in root cells. Planta 108: 103-120.

- 1974. Fine structure and cytochemistry of the abscission zone cells of Phaseolus leaves. II. Localization of peroxidase and acid phosphatase in the separation zone cells. Ann. Bot. 38: $855-858$.

Henry, E. W., Valdovinos, J. G. and Jensen, T. E. 1971. Ethylene enhanced peroxidases in abscission cells of tobacco flower pedicels. Plant Physiol. Lancaster 47 (Supplement): 83.

- and Jensen, T. E. 1973. Peroxidases in tobacco abscission zone tissue I. Fine-structural localization in cell walls during ethylene-induced abscission. J. Cell Sci. 13: 591-601.

—, Valdovinos, J. G. and Jensen, T. E. 1974. Peroxidases in tobacco abscission zone tissue II. Time course studies of peroxidase activity during ethylene-induced abscission. Plant Physiol. Lancaster 54: 192-196.

- 1975a. Peroxidases in tobacco abscission zone tissue III. Ultrastructural localization thylakoids and membrane-bound bodies of chloroplasts. J. Ultrastruct. Res. 52: 289-299. 
- 1975b. Peroxidases in tobacco abscission zone tissue IV. Fine structural localization in endoplasmic reticula during ethylene-induced abscission. Caryologia 28(4): 477-487.

- 1977. Peroxidases in tobacco abscission zone tissue V. Time course studies of polyphenol oxidase activity during ethylene-induced abscission. Zeit. für Pflanz. 84(5): 419-426.

Hepler, P. K., Rice, R. M. and Terranova, W. A. 1972. Cytochemical localization of peroxidase activity in wound vessel members of Coleus. Can. J. Bot. 50: 997-983.

Israel, H. W. and Steward, F. C. 1967 . The fine structure and development of plastids in cultured cells of Daucus carota. Ann. Bot. 31 : 1-18.

Jensen, T. E. and Valdovinos, J. G. 1967. Fine structure of abscission zones. I. Abscission zones of the pedicels of tobacco and tomato flowers at anthesis. Planta 77: 298-318.

- 1968. Fine structure of abscission zones III. Cytoplasmic changes in abscising pedicels of tobacco and tomato flowers. Planta 83: 303-313.

- 1972. Fine structure of abscission zones IV. Effect of ethylene on the ultrastructure of abscission cells of tobacco flower pedicels. Planta 102: 324-333.

Kosuge, T. 1969. The role of phenolics in host response to infection. Ann. Rev. Phytopath. 7: 195-222.

Legg, P. G. and Wood, R. L. 1972. Effects of allylisopropylacetamide (AIA) on the fine structure and peroxidase activity of microbodies in rat hepatic cells. Z. Zellforsch. Mikrosk. Anat. 128: 19.

Luft, J. H. 1961. Improvements in epoxy resin embedding methods. J. Biophys. Biochem. Cytology 9: 409-414.

Mapson, L. W. and Wardale, D. A. 1972. Role of indolyl-3-acetic acid in the formation of ethylene from 4-methylmercapto-2-oxo butyric acid by peroxidase. Phytochem. 11: 1371-1387.

Margoliash, E. and Novogrodsky, A. 1958. A study of the inhibition of catalase by 3-amino-1, 2, 4-triazole. Biochem. J. 68: 348-468.

-, Novogrodsky, A. and Schejter, A. 1960. Irreversible reaction of 3-amino-1, 2, 4-triazole and related inhibitors with the protein catalase. Biochem. J. 74: 339-348.

McCune, D. C. 1961. Multiple peroxidases in corn. Ann. NY Acad. Sci. 94: 723-730.

Morita, Y., Kameda, K. and Mizuno, M. 1962. Studies on phytoperoxidase XVI. Aerobic destruction of indole-3-acetic acid catalyze by crystalline Japanese radish peroxidase a and c. Agric. Biol. Chem. 26: 442-446.

Nir, I. and Seligman, A. M. 1971. Ultrastructural localization of oxidase activities in corn root tip cells with two new osmiophilic reagents compared to diaminobenzidine. J. Histochem. Cytochem. 19: 611-620.

Novikoff, A. and Goldfischer, S. 1969. Visualization of peroxisomes (microbodies) and mitochondria with diaminobenzidine. J. Histochem. Cytochem. 17: 675.

Novikoff, A. B., Novikoff, P. M., Quintana, N. and Davis, D. 1972. Diffusion artifacts in 3, 3'diaminobenzidine cytochemistry. J. Histochem. Cytochem. 20: 745.

Ridge, 1. and Osborne, D. J. 1970. Regulation of peroxidase activities by ethylene in Pisum sativum: Requirements for protein and RNA synthesis. J. Expt'l. Bot. 21 : 720-734.

Scott, P. C., Miller, L. W., Webster, B. D. and Leopold, A. C. 1967. Structural changes during bean leaf abscission. Amer. J. Bot. 54: 730-734.

Seevers, P. M., Daly, J. M. and Catedral, F. F. 1971. The role of peroxidase isoenzymes in resistance to wheat stem rust disease. Plant Physiol. Lancaster 45: 353-360.

Seligman, A. M., Karnovsky, M. J., Wasserkrug, H. L. and Hanker, J, S. 1968. Nondroplet ultrastructural demonstration of cytochrome oxidase activity with a polymerizing osmiophilic reagent, diaminobenzidine (DAB). J. Cell Biol. 38 : 1.

Sexton, R. and Hall, J. L. 1974. Fine structure and cytochemistry of the abscission zone cells of Phaseolus leaves. I. Ultrastructural changes occurring during abscission. Ann. Bot. 38 :(157) $849-854$.

Valdovinos, J. G. and Jensen, T. E. 1968. Fine structure of abscission zone II. Cell wall changes in abscising pedicels of tobacco and tomato flowers. Planta 83: 295-302.

-, - and Sicko, L. M. 1971. Ethylene-induced rough endoplasmic reticula in abscission cells. Plant Physiol. Lancaster 47: 162-163. 
- 1972. Fine structure of abscission zones IV. Effect of ethylene on the ultrastructure of abscission cells of tobacco flower pedicels. Planta 102: 324-333.

VanOverbeek, J. 1935. The growth hormone and the dwarf type of growth in corn. Proc. Natl. Acad. Sci, USA. 21 : 292-299.

Vetter, J. 1973. Fiatal es idos dohany-kalluszszovet peroxidaz-es RNaz-aktivitasainak osezehasonlitasa. Bot. Kozlem. 60. Kotet. 4: 221-224.

Vigil, E. L. 1969 . Intracellular localization of catalase (peroxidatic) activity in plant microbodies. J. Histochem. Cytochem. 17: 425-428.

- 1970. Cytochemical and developmental changes in microbodies (glyoxysomes) and related organelles of castor bean endosperm. J. Cell Biology 46: 435-454.

Webster, B. D. 1968. Anatomical aspects of abscission. Plant Physiol. 43: 15×2-1544.

- and Leopold, A. C. 1972. Stem abscission in Phaseolus vulgaris explants. Bot. Gaz. 133(3): 292-298.

- and Chiu, H. W. 1975. Ultrastructural studies of abscission in Phaseolus: Characteristics of the floral abscission zone. J. Am. Hort. Sci. 100(6): 613-618. 